\title{
Orozomukoid és sziálsav - szerkezet, funkció, klinikai vonatkozások
}

\author{
Jakab Lajos dr. \\ Semmelweis Egyetem, Orvostudományi Kar, III. Belgyógyászati Klinika, Budapest
}

\begin{abstract}
A közlemény az orozomukoid és ezen belül a sziálsav molekuláris szerkezetét, strukturális sajátosságát mutatja be, valamint ismerteti élettani, kórélettani és klinikai tulajdonságait, illetve szerepét. Az orozomukoid a lipokalinok családjába, illetve az immunokalinok családjába tartozó, az immunrendszerre ható antiinflammatoricus, valamint transzportmolekula. Az orozomukoid további sajátossága, hogy lektinekhez tud kapcsolódni. Az orozomukoid elterjedt a természetben, és további vizsgálata révén a funkciójával, biológiai szerepével kapcsolatos ismeretek is gazdagodni fognak. A cikkben a klinikai vonatkozások is említést nyernek.
\end{abstract}

Orv Hetil. 2019; 160(8): 283-290.

Kulcsszavak: orozomukoid, sziálsav, szerkezet, funkció, klinikai vonatkozások

\section{Orosomucoid and sialic acid - structure, functions, clinical relations}

The work focuses on orosomucoid. First, the biological role and the development of this essential molecule is summarized, then the formation of its special molecular structure is introduced. After the summary of the specific characteristics and the physiological, pathophysiological as well as clinical properties of orosomucoid and sialic acid, their most important roles are also presented. Orosomucoid belongs to the family of lipocalins and the subfamily of immunocalins - this determines its immunological, anti-inflammatorical and transporting capacities. Another important quality of the molecule is that it is recognized by lectins. Orosomucoid is highly bioactive. More knowledge is increasing about its function and biological role. The clinical relations are summarised, too.

Keywords: orosomucoid, sialic acid, structure, functions, clinical importance

Jakab L. [Orosomucoid and sialic acid - structure, functions, clinical relations]. Orv Hetil. 2019; 160(8): 283-290.

(Beérkezett: 2018. szeptember 4; elfogadva: 2018. október 27.)

\section{Rövidítések}

$\mathrm{AGP}=(\alpha \mathrm{l}$-acid-glycoprotein $) \alpha \mathrm{l}$-savas glikoprotein; $\mathrm{APR}=$ (acute-phase reactant) akutszervezetiválasz-reaktáns; CEA = (carcinoembryonic antigen) carcinoembryonalis antigén; CRD $=($ carbohydrate recognition domain $)$ szénhidrát-felismerő domén; CRP = C-reaktív protein; GP = glikoprotein; GPR $=$ glikoproteinreceptor; IL = interleukin; INF = interferon; Infl. = inflammatio; IR = immunrendszer; LED = lupus erythematosus disseminatus; $\operatorname{Lp}(\mathrm{a})=\operatorname{lipoprotein}(\mathrm{a}) ; \mathrm{Mo}=$ monocyta $; \mathrm{PCP}$ $=$ polyarthritis chronica progressiva; $\mathrm{Sia}=($ sialic acid $)$ sziálsav; sLeX = sLewisX; Sn = szialoadhezin; SSA = szérum-amiloid A; STAT3 $=$ signal transducers and activator of transcription + p65 protein; TGF $=$ (transforming growth factor $)$ transzformáló növekedési faktor; TNF = tumornekrózis-faktor
„Sunt animae rerum” (A dolgoknak lelkük van.)

A máj, mint az egész szervezet anyagcsereközpontja és mint másodlagos immunszerv, különleges szöveti felépítéssel rendelkezik. Teljes vérellátása 1,5 1/min, amelynek körülbelül $80 \%$-a a portocavalis rendszerből származik. A speciális folyamatok ellátását a májszövet különleges anatómiai, szövettani szerkezete teszi lehetóvé. A parenchymát a sinusoidok összefüggő rendszere szövi át. A májban fellelhető makrofágok az egész szervezetben található makrofágok mintegy $80 \%$-át reprezentálják. A dendritikus és a sajátos Kupffer-sejtek a sinusoidokban a májban található limfoid elemek 15\%-át teszik ki. 
A makrofágok jelentős hányada a mikrostruktúrákba épül be, amelyek különleges felépítése teszi lehetóvé a direkt és indirekt találkozást a májparenchyma és az úgynevezett nem parenchymalis sejtek (Kupffer-sejtek, Itosejtek, sinusendothelsejtek stb.) között. A máj a vérbe jutó fehérje- és nem fehérjemolekulák fö termelődési helye. Döntő részben itt képződik a sziálsav (Sia) is. Ezek egy része itt hagyja el a vérkeringést, itt kerül kiválasztásra (szialo-GPR-ok, vagyis glikoproteinreceptorok). A Sia és az orozomukoid egyedi szerkezetü, multifunkcionális molekulák, amelyek az élő szervezet minden szövettípusában fellelhetők [1-5] (1. táblázat).

\section{Szerkezet, múködési mechanizmusok}

A molekula egyedi megjelölése $\alpha \mathrm{l}$-savas glikoprotein (AGP), orozomukoid. Fehérje és oligoszacharid, glikán részekből tevődik össze. A sejtek, molekulák (fehérje, zsír) csaknem kivétel nélkül tartalmaznak Sia-t. Az orozomukoid a lipokalinfamília, ezen belül az immunokalinszubfamília tagja. A 183 aminosavból felépülő polipeptidlánc általában maximum 6 oligoszacharidcsoportot tartalmaz. Az alapszerkezet tehát tipikus glikoprotein (GP). Moláris tömege $4 \mathrm{l}-43 \mathrm{kD}$, de akad 48-49 kD tömegü formája is. Az oligoszacharidláncok tömege a molekula mintegy 48\%-át teszi ki. A terminális 18 aminosav mobilisabb, úgynevezett szignálpeptid. Az oligoszacharidláncok (ált. 2-5) N-glikoid és O-glikoid formában stabilan kötöttek a polipeptidlánchoz. A molekula izo- elektromos pontja alacsony $(\mathrm{pH}=2-3$ körüli). $\mathrm{Az}$ oligoszacharidláncok molekulái a galaktóz, a glükózamin, a mannóz, a fukóz és a láncvégi Sia.

A molekula szintézisét 3 gén vezérli. Közülük az első gén a domináns, a másik kettő alárendelt jelentőségünek látszik. A humán vérben található orozomukoidmennyiség élettani körülmények között csaknem 100\%-ban a domináns gén származéka. Átlagkoncentrációja körülbelül $75 \mathrm{mg} / \mathrm{dl}$. Korábban az volt a feltételezés, hogy az orozomukoid a legnagyobb szénhidráttartalmú molekula a humán vérben. Kiderült azonban, hogy a galakto-GP nagyobb, a maga 75\%-os oligoszacharid-tartalmával [6-8].

$\mathrm{Az}$ orozomukoid az úgynevezett „akutfázis-proteinek” közé sorolható. Az orozomukoid koncentrációja az akut szervezeti válasz folyamán jelentősen - körülbelül az ötszörösére - emelkedik, ezért is megfelelőbb az akutszervezetiválasz-reaktáns (APR) kifejezés. Az APR-ok élettani vérkoncentrációja alacsony, de néhány APR koncentrációemelkedése akár $1000 \times$-es is lehet a szérumban az akut szervezeti válasz kapcsán. Ezen reaktánsok döntő hányada szerkezetileg GP-t és Sia-t, továbbá olyan, döntő többségben GP APR-okat is tartalmaz, amelyek szérumbeli koncentrációja csökken a szervezeti akut válasz idején. Az akut szervezeti válaszban szinte valamennyi vérbeli komponens részt vesz, de az APR-ok különböző irányban és mértékben módosulnak az akut szervezeti válasz folyamán.

A szervezeti válaszreakció tehát általános, az akutan reagáló és akutan nem reagáló szérumkomponensek megkülönböztetése szükségtelen. Ez a különböző mér-

1. táblázat | Akutfázis-reaktánsok

\begin{tabular}{|c|c|c|c|}
\hline$\alpha$-amiloid (GP) & \multirow{3}{*}{$1000 \times$} & $\mathrm{C} 3$ & Albumin \\
\hline CRP & & $\mathrm{C} 4$ & $\alpha 2 \mathrm{HS}-\mathrm{GP}$ \\
\hline Hepcidin & & C9 & Transzferrin \\
\hline Pentraxin-3 & \multirow[t]{2}{*}{$800 \times$} & C4B-kötő-pont & Hisztidingazdag GP \\
\hline Lipokalin & & Faktor B & Angiotenzinogén \\
\hline Sia & \multirow{7}{*}{ A-típus } & Cl-inhibitor & Tiroxinkötő prot. \\
\hline Neutrophil-zselatináz-asszoc. lipokalin & & Coeruloplazmin & Inzulinszerü növekedési faktor \\
\hline al-mikroglobulin & & Haemopexin & Transztiretin \\
\hline Prosztaglandin C & & Plazminogén akt. & Factor-XII \\
\hline Szintáz & & \multicolumn{2}{|l|}{ Plazminogén akt. inhib. } \\
\hline Glikokalin & & \multicolumn{2}{|l|}{ Protein-9 } \\
\hline Co-faktor 3 subunit & & \multicolumn{2}{|l|}{ Szöveti plazminogén akt. } \\
\hline Fibrinogén & \multirow{3}{*}{ B-típus } & \multicolumn{2}{|l|}{ ILl-antagonista } \\
\hline a2-haptoglobin & & \multicolumn{2}{|l|}{ LPS-kötő fehérje } \\
\hline$\alpha \mathrm{l}$-antikimotripszin & & \multicolumn{2}{|l|}{ Mannankötő fehérje } \\
\hline Leukaemiainhib. faktor & \multirow{5}{*}{ 3-típus } & \multicolumn{2}{|l|}{ Fibronektin } \\
\hline IL-11 & & \multicolumn{2}{|l|}{ Vitronektin } \\
\hline Ciliaris neurotroph & & \multicolumn{2}{|l|}{ Szelektinek } \\
\hline \multicolumn{3}{|l|}{ Onkosztatin $\mathrm{M}$} & \\
\hline Kardiotrofin-1 & & & \\
\hline
\end{tabular}


tékű, irányú válasz messzemenően szervezetten, a neuroendokrin rendszer által, az agykéreg legfóbb irányításával megy végbe. A reaktánsok fó termelődési helye a máj, a hepatocyták. A májon kívül a válasz idején még különböző sejtek (például a makrofágok, a Mo-k, a granulocyták, az endothelialis és a microgliasejtek) képesek APR-termelésre. A neuroendokrin rendszer a fó szabályozó, de kifejezetten aktív a naturális és az adaptív immunrendszer is, továbbá a citokinek is közremúködnek a szabályozásban. A feladat a károkozás jellegétől, mértékétôl és a szervek állapotától is nagymértékben függ [9-12]. A szervezeti válaszreakció feladata az ártalom elhárítása, az Infl. finom, adekvát regulációja, az elhárítórendszer pontos szabályozása, hogy a restitutio ad integrum bekövetkezhessen. A szervezetet a túlszabályozott és az alulszabályozott válasz egyaránt megterheli. $\mathrm{Az}$ orozomukoid minden fázisban tevékeny résztvevője a válaszreakció szabályozásának, mind mennyiségbeli változása, mind a molekuláris szerkezet változása révén.

Változások történnek a polipeptidláncban, illetve az orozomukoid oligoszacharid láncában. A láncok szerkezeti változásainak száma növekedhet. A bi- és triantennáris szerkezetek helyett a tri- és tetraantennáris szerkezetek kerülnek túlsúlyba. Nem ab ovo súlyos mértékú a károsodás, hanem adekvát a változások összessége, jól védekezik a szervezet. Az orozomukoidkoncentráció gyorsan rendeződik, de a glikoform társulások még hat hónap után is árulkodnak a lezajlott „csatáról”. A beható károsodás mértéke természetesen meghatározó lehet. A károsodás helyreállításában részt vevő szervek, szervrendszerek korábban említésre kerültek [13, 14]. Elengedhetetlenek a monokinek, a citokinek és a növekedési faktorok, például az IL1, IL6, TNF, INF; egyéb citokinek, például TGF; a kortikoszteroidok, az APR-ok, köztük néhány kiemelkedő: orozomukoid, CRP, SSA stb. moduláns molekulák, inhibitorok. Kiemelendő még a Sia részvétele, a szelektinek [E, P, L], a sialyl LeX csoport, és nem utolsóként a lektinek szerepe. Az APR-ok között a már említetteken túl a SSA (szérum-amiloid A), a CRP és nem utolsósorban a komplementrendszer jelenti a védekezés eszköztárát az immunrendszerrel együtt. Infl.-gátló a TGF (transforming growth factor). A már említett APR-sor is kiegészíthető; az úgynevezett konstitutív tagok, az albumin, a retinolkötő fehérje, illetve a transzferrin említhető. Hangsúlyozni kell az egyedi, specifikus hatások mellett az összehangolt együtthatás szerepét.

A károsító behatás, az elhárító válasz a szervezeti alapelemekig hatolhat. Az a2-makroglobulin koncentrációja egyedi változásokat mutat. Az APR-ban az ILl inkább gátlóhatású, és csak hetekkel, esetleg hónapokkal később emelkedik meg az $\alpha 2$-makroglobulin szintje, ami a TGF gátlóhatásának jele is lehet. Az orozomukoid-hiperfunkció anti-Infl.-s hatással bír. A direkt kapcsolat az E-szelektin és a sLeX-gyök között arra utal, hogy az endotheliumon csökken az extravasatio, fóként a granulocytafelismerés, a kapcsolódás, a görgés megszûnése (L-,

\section{2. táblázat Sia-előfordulás (szövetek, sejtek)}

\begin{tabular}{l|l}
\hline $\begin{array}{l}\text { Központi idegrendszer } \\
\text { Cardiovascularis rendszer } \\
\text { Respiratorikus rendszer }\end{array}$ & $\begin{array}{l}\text { Lektinek is } \\
\text { Cor, vasa, endothelium } \\
\text { Pulmo, pneumocyta II, pulm. } \\
\text { fibroblast, alveolaris makrofág }\end{array}$ \\
$\begin{array}{l}\text { Vesék } \\
\text { Lép } \\
\text { Genitalis rendszer }\end{array}$ & $\begin{array}{l}\text { Mamma, mamma epithelium, decidua, } \\
\text { prostata epithelium, testis, uterus } \\
\text { Ventriculus, ileumepithelium, colon }\end{array}$ \\
$\begin{array}{l}\text { Gastrointestinum } \\
\text { Zsírszövet } \\
\text { Vérképzés }\end{array}$ & $\begin{array}{l}\text { Granulocyta, lymphocyta (nem az } \\
\text { összes), monocyta }\end{array}$ \\
Legfontosabb: májszövet, hepatocyta
\end{tabular}

P-, E-szelektinek), illetve a hepatocyták által termelt reaktánsok miatt. Ezek szabályozását transzkripciós faktorok végzik meghatározott jelek hatására. A komplex, finoman összehangolt irányítás föképp a STAT3 (signal transducers and activator of transcription + p 65 protein) közremúködésén alapszik. IL6 is szintetizálódik, ez talán a legfóbb stimulus. A granulocyta termelte orozomukoidmolekulák tömege nagyobb, mint 48-50 kD [15-18] (2. táblázat).

A szervezeti válaszreakció lecsengésében fontos mozzanat a sejtextravasatio gátlása, megszúnése. Az APRban az Infl.-nak megfelelően aktiválódnak a sejtes elemek, például Mo-k, makrofágok stb. A Mo-k membránján kétféle receptor található. Ezek száma 600 és 1200/sejt, míg a granulocyta esetében 3500/sejt. Az endotheliumon található scavenger típusú receptorok feltételezhetően szelektíven kötnek orozomukoidot. A felismerési folyamatok nem minden esetben tisztázottak. Lehetséges, hogy a patogének termelte Sia a kulcspont. Elképzelhető, hogy a gazdasejt oligoszacharidjaiból, illetve az idegen sejtből származó transszialidáz révén mobilizálódik a Sia-molekula. Lehetséges, hogy Sia fogva van tartva a gazdasejtben, talán a citokin-monofoszfát-Sia alakzatban, ahonnan membrántranszferáz juttathatja tovább. Végül az is lehetséges, hogy nem ismert a Sia-forrás (például a Guillain-Barré-szindróma egy része). Külön lehetne a szervezeti APR-ok klinikai vonatkozásait érinteni, megismer(tet)ni a válaszmolekulák egyedi változásait, de mindebből most csak annyit említünk, hogy egyes megfigyelések a kötődő, transzportáló lipokalinfamília bizonyos szubfamíliatagjaira hívják fel a figyelmet. Idesorolható a már tárgyalt orozomukoid mellett többek között a glikokalin, az al-mikroglobulin, a glikodelin (krónikus 9), a prosztaglandin-D-szintáz, a kofaktor-8 neutrophilalegység, a zselatinázasszociált lipokalin és a könnyprealbumin [19-21].

\section{Lektinek, Sia-felismerő lektinek}

A lektinek szénhidrátfelismerő molekulák. A felismerést kötődés követi. A Sia-t felismerő lektinek száma nagy. 
Ezek csak a láncvégi, terminális pozícióban elhelyezkedő Sia-t ismerik fel; így jöhet létre a felismerés-kötődés a lektin és a specifikus fehérje között a specifikus kötőhelyen, a GP-molekulán. Ez általában nem valódi receptorszerkezet, de mindenképpen sajátos, kitüntetett locus (hot point). Az oligoszacharidtartalmú proteinmolekulákban az oligoszacharidelágazódások, a fukoziláció mértéke, a sLeX jelenléte a láncon elősegíti a Sia felismerését. Nem minden oldallánc tartalmaz fukózt, sőt még a láncvégi Sia is hiányozhat olykor. A sLeX tetraszacharid, fukózszerkezettel. A glikáncsoportok végződései mindig fontosak, a felismerési folyamatokban meghatározó a szerepük. 50 körül van a természetben a Sia-molekulák finom konformációváltozatainak száma. Mind a humán, mind a csimpánzeredetúek egy részében a makrofágok tartalmaznak Sia-t. A felismerés feltétele legalább két Sia-szerkezet megléte. Valószínú, hogy a szialoadhezin $(\mathrm{Sn})$ is felismer, és felismerés után múködtet három különböző felismerőmolekulát. Az argininmolekula elengedhetetlen a Sia felismeréséhez. A humán Sia-szerkezetek specifikus feltételek esetén formai módosulások alanyai. A teljes sialoma változásainak vonatkozásában vannak még tisztázatlan mozzanatok, és az esszenciális molekulák membránszerkezetekbe való kapcsolódásának egyes részletei sem ismertek tökéletesen. A Sn megkülönböztetett jelentőséggel bír a CD33, a CD22, a Siglec-5 és a Siglec-6 hatásának alakításában. A Sn-pozitív hatások és a makrofágok feltehetőleg kapcsolatban állnak az ember evolúciójával [22-24].

$\mathrm{Az}$ élő szervezetekben a sejtes és molekuláris felismerések alakították az orgánum továbbfejlődését. A fejlődésben a folyamatos változások nagyobb egységek, nagyobb molekulák létrejöttét eredményezték. Idesorolhatók a mucinsavak, a nukleinsavak, a fehérjék, a glikánok, a lipidek ismert alakzatai. Különösen szembetűnő a szénhidrátok változékonysága. Az immunrendszer (IR) naturális és adaptációs formája példaértékủ módozatai ennek. Az IR sejtállománya, a komplementrendszer, a molekuláris mintázatot felismerő rendszerek (a kollektinek, a properdinrendszer, a fikolinok, a pentraxinok) például szolgálnak $[25,26]$ (3. táblázat).

Egyedülálló felismerési rendszert állít elénk az antigén-antitest képződés és kötődés, illetve a lektinnagyrendszer. A lektinek által felismert molekulák: galaktóz, mannóz, fukóz, hexózamin, Sia stb. struktúrája. Ez a Sia-nak a természetben, a növény- és állatvilágban való elterjedtségének magyarázata. A fehérje-glikán duális rendszeren belül fellelhetố a konzervált, szénhidrátfelismerö domén (CRD, carbohydrate recognition domain) molekulaszakasz. A szénhidrátkötőhely (receptortípusú, ekvivalens) specifikus, bár egyes esetekben található átfedés. A felismerőszerkezetek heterogén molekulák. Ezek együttesen alkotják az I-típusú lektinfamíliát. Az I-típusú lektinek famíliájának szubfamíliáját alkotják az úgynevezett Sia-felismerő lektinek, vagyis a Siglec-ek. Ezek szinte kizárólag Sia-felismerő lektinek; de a kivételek tisztázása, felismerése még nem zárult le [27].
3. táblázat |Sia, lektinek, vírusok (példák)

\begin{tabular}{ll}
\hline $\begin{array}{l}\text { 1. Orthomyxoviridae } \\
\text { (például influenza A, B, C) }\end{array}$ & $\begin{array}{l}\text { Hemagglutinin, } \\
\text { neuraminidáz, } \\
\text { glikoproteinek }\end{array}$ \\
\hline $\begin{array}{l}\text { 2. Paramyxoviridae } \\
\text { (például Newcastle v., parainfluenzav.) }\end{array}$ & Hemagglutinin \\
\hline $\begin{array}{l}\text { 3. Polyoma v. } \\
\text { (például humán polyomav.) }\end{array}$ & Sia (módosult) \\
\hline $\begin{array}{l}\text { 4. Coronaviridae } \\
\begin{array}{l}\text { 5. Reoviridae } \\
\text { (például Reovirus, Rotavirus, Simian } \\
\text { virus, egyéb törzsek) }\end{array}\end{array}$ & $\begin{array}{l}\text { Oligoszacharid } \\
\text { Sia-származék) }\end{array}$ \\
\hline $\begin{array}{l}\text { 6. Adenoviridae } \\
\text { (például adenovírusok 37, 8, 19) }\end{array}$ & Sia-szerkezetek \\
\hline $\begin{array}{l}\text { 7. Picornaviridae } \\
\text { (például enchephalomyocarditis, } \\
\text { rhinovirus, humán enterov., } \\
\text { hepatitis A-vírus) }\end{array}$ & Sia, Sia-származékok \\
\hline $\begin{array}{l}\text { 8. Parvoviridae } \\
\text { (például Canine parvov., Feline parvov., }\end{array}$ & Sia \\
Murine parvov.) & Sia \\
\hline $\begin{array}{l}\text { 9. Herpesviridae } \\
\text { (például humán cytomegalov.) }\end{array}$ & Sia (szerkezet) \\
\hline $\begin{array}{l}\text { 10. Hepatitis B-vírus } \\
\text { Sia-szerkezet }\end{array}$ \\
\hline
\end{tabular}

A Sia egy 500 millió év alatt kialakult formáció, amely jelenleg önmagában mintegy 50 -féle végtermékre utal. Meghatározó a gyök, a szializáció mértéke, a sialyl LeX jelenléte és a fukoziláció mértéke. A terminális glikánláncvégződések is mindig meghatározóak. A Sia végződésú láncok száma még feltárásra vár.

Az Ig (immunglobulin) ősi, divergens molekula. Eleinte úgy tûnt, hogy homogén molekuláris csoportosulásról van szó. A szuperfamília-tagok homeotípia-heterotípia konvergencia alapján egyesülnek, funkcionálnak. Bár már korábban ismert volt az adhéziós molekulák, valamint a neurális adheziós molekulák felismerőképessége és kapcsolatteremtő kapacitása, a megismerés akkor lett tökéletes, amikor kiderült a molekuláris glikánok fontossága, valamint a Sn (szialoadhezin)-szerkezet fehérje + glikán (GP) alkotta egysége. A Sn volt a prototípus, amelynek felismerési tulajdonsága nyilvánvalóvá vált, és tisztázódott, hogy hibrid molekula. Kiderült, hogy hasonló molekuláris struktúrák széles körben fellelhetők.

A Sn- „felhő” fehérjét és Sia-t tartalmaz. Szialidáz hatására e „felhő” fellazul, felhígul, a CD22 megközelíthetővé válik. Ez lehetôvé teszi a sejt + sejt kapcsolatot. „Kinyílt" a membrán, kiderült, hogy az kötődik lipidekkel, GP-ekkel. Jelenleg nem ismeretes, hogy a természetben mennyi Siglec-molekula létezik az eddig ismerteken túl (jelenleg körülbelül 20-at ismerünk). A Siglec-ek olyan "fehérje-" molekulák, amelyek aminoterminálisan „V-set Ig-like domaint" birtokolnak, a kontaktus helyén receptorszerú locust hordoznak. Itt történik a Siglec-kapcsolódás a terminális Sia-hoz. Ez a jelenség igen gyakori. 
A „kémiai” szérumproteinek csaknem kivétel nélkül GP-ek. Ismert ugyan, hogy néhány, különböző tömegú molekula fehérje [28-30]. A szervek, a szövetek, valamint a mátrixbeli molekuláris elemek sokasága tartalmaz Sia-t.

Mindeddig a Sia-ról és az azt felismerő-kötő alkatrészekről esett szó. Nagyon fontos a Sia-felismerő lektinekról és ezek funkcióiról is szót ejteni. Az bizonyos, hogy speciális jelenségről, kötési módról és rögzítőmechanizmusról van szó. A kötődés, a jelek képződése, azok megfelelő irányítása, bekapcsolódása az intracelluláris alapfunkciókba meghatározó történések. Az alapjelenségek kiváltása nem csak in loco a károsodott szövetben történik. A kiváltó hiba elhárítása, majd a rekonstrukció kiemelt jelentőségú. Ennek eszközei a szervezeti elhárító reakcióba beépült folyamatok, ezek közül is a Sia-szerep mérhetetlenül fontos. A lektinek munkálkodása folyamatosan nyomon követhető.

A Sia nem túlságosan bonyolult szerkezet, de a szervezetben fontos szereplő. A természetben körülbelül $10^{5}$ körül van a glikoformok elképesztő száma. Egészséges

4. táblázat | Sziálsav (Sia)-felismerő szerkezetek (Siglec-sz.)

\begin{aligned} \hline Siglec & \\ \hline 1 & Szialoadhezin, makrofág, CD 8 subset, granulocyta, NK, B \\ & ly, Sn - makrofág, haematopoesis \\ 2 & Szialoadhezin, MAGP (microglia asszociált GP), B ly, CD 22 \\ 3 & NK ly, makrofág, Mo, granulocyta, MAGP, fibronektin, \\ & tenascin receptor, AML, CLL, CD 33 \\ 4 & Mo, makrofág, granulocyta, MAGP, fibronektin, tenascin \\ & receptor, neurotrofin receptor \\ 5 & Mo, makrofág, granulocyta, dendrit s. Tn epitop, neuron \\ & kapcs.: Sia, orozom., Siglec-14: védelem \\ 6 & Ly, Trophblastaffinitás: szelektin, spec. köt.: leptin \\ 7 & Nk, CD 8, Mo, makrofág, Ly, Ma-Sn counter receptor. \\ 8 & Eo, T ly, spec. kapcs. szelektinek, sLeX \\ 9 & Granulocyta, Mo, NK, B ly, CD 8 ly, Ma, Counter receptor: \\ 14 & CD 45-CD 2 \\ 10 & Makrofág \\ 11 & Microglia, a2-inhibitor, membránsejtsűrüség-felismerés, \\ & MAGP \end{aligned}

Megjegyzések: Siglec 3 related: 3, 5, 6, 7, 8, 9, 10, 11 Siglec 5, 6, CD22, CD33 kettős epitop felismerése Siglec bázikus ligandum: szializált tip. I, II, III diszacharid

Széles körü elterjedtség, mieloid, neuronsejt, neurongátló receptor: CD4-molekula Siglec: széles elterjedtség: makrofág Mo, Ly, oligodendrocyta széles elterjedtség: CD 200-CD 200R: neuron-microglia egyensúly humán viszonylatban 10-20 között lehet a szükséges Sia-glikoformok előfordulása, ám patológiás helyzetben ez a szám a sokszorosára növekedhet. Ebben az esetben a kóros glikoformok, a kóros Sia-szerkezetek kóros glikoformációt kreálnak. Már említést nyert, hogy az alaporozomukoid a lipokalincsaládba tartozik. Hidrofób molekulákat köt, immunmodulátor, és anti-Infl. hatással rendelkezik. Az említetteken túl találhatók olyan lektinek, amelyek $\mathrm{SO}_{4}$-csoportokat, poliszacharidokat, glükózaminoglikánokat tartalmaznak, kötnek meg. Ezek mind az I-típusú lektinek famíliájába sorolhatók (4. táblázat).

\section{Klinikai vonatkozások}

A megelőzőkben már történt utalás egyes klinikai vonatkozásokra. Ennek kiegészítéseként utalnánk a klinikumot érintő megfigyelésekre. Post partum periódusban a szérumorozomukoid-koncentráció változásait vizsgálva feltûnt, hogy partus után 2 és 17 héttel még jelentős változások zajlanak. Az orozomukoidváltozások esetében 73\%-kal, illetve 29\%-kal, a CRP-koncentráció esetében 58\%-kal és 26\%-kal magasabb értékek találhatók az élettani értéknél. Ugyanakkor a Fe-anyagcserével összefüggő ferritin és hepcidin (APR) esetében inkább csökkent a koncentráció. Germinális sejtes tumorokban vizsgálódva az $\mathrm{N}$-glikán-mennyiség jelentősen megemelkedik. Az össz-N-glikán-mennyiség tartalmazza a specifikus tumormarkereket is. Néhány (4-5) molekula specifikusnak tünt, de ezek kapcsolata az orozomukoiddal nem tisztázott [31-33].

Öt APR szérumbeli koncentrációját meghatározva megállapítható volt, hogy az al-antitripszin, a C3-as komplementkomponens és a CRP összefüggést mutatott az artériafal merevségével, a cardiovascularis történésekkel [34]. Az orozomukoidkoncentráció és az összhalálozás között kapcsolat volt a vizsgálatok első öt évében. A további években csak az IL6 és a CRP mutatott ilyen tulajdonságot [35]. Sepsisben a szérum- és vizeletbeli orozomukoidtartalom összefüggésben van a klinikai képpel. A jelenség a vizeletbeli eltérés tekintetében szorosabb összefüggést mutat a klinikummal. A szérumorozomukoid-koncentráció akár az 1000×-es emelkedést is elérheti. A vizeletorozomukoid-tartalom élettani értéke alacsony. A prokalcitonin és a CRP meghatározása elengedhetetlen sepsisben. A preszepszin (CD14-mintázat-felismerő receptor) is pozitív korrelációban van a szérumszinttel és a kórfolyamat-változással [36]. A colorectalis tumor CEA-pozitivitást mutat. A tumor egyes stádiumaiban a CEA-glikoziláció specifikus változásokat mutat, így hatékony eszközként szolgálhat a betegség pontos diagnosztizálásában. Az ép szövetből és a tumorból származó CEA felépítése különbözik. A tumorsejtekben a Thomsen-Friedenreich-antigén, a glükóz- és a mannóztartalom megnövekedett, míg az N-acetil-hexózaminok, a molekuláris elágazódások és a biantennáris N-glikánok száma az egészséges sejtekéhez képest ala- 
csonyabb. A tumorokból származó N-glikán stabil GP, molekuláris tömege 180-200kD. A glikánösszetétel változó. A galaktóz, a mannóz, a glükózamin, a fukóz és Sia stabil komponensek. A tumoreredetű CEA-kban található LewisX, LewisY mannózelágazó glikánok [37, 38].

A lipoprotein(a) [Lp(a)] egyik összetevője az erősen glikolizált $\operatorname{apo}(\mathrm{A})$. Feltételezések szerint a szialo-GPRok révén jut a keringésból a szövetekbe. A plazma Lp(a)tartalmát összefüggésbe hozzák az atherogenesissel. Molekuláris kompozíciója, keletkezése, metabolizmusa széles körü vizsgálatok tárgya. Bizonyos, hogy az aortafal felépítésében alapvetően proteoglikánok, glükózaminoglikánok kötődnek Lp(a)-hoz [33].

A komplexkapcsolódás az artériafal szerkezetének része [az Lp(a)-val együtt]. Az artériafalban krónikus inflammatio generálódik, csökken az artériafal rugalmassága [39]. Az orozomukoid, a CRP és az IL6 koncentrációja mutatja a legszorosabb kapcsolatot az érfali elváltozásokkal. Bár a szérumbeli orozomukoidváltozás, -jelenlét tartós, közvetlen ok-okozati összefüggést nem mutat az érfali változásokkal. A Sia-felszaporodás a szervezeti védekezés jele, általában nem ab ovo patológiás folyamat. Emellett elmaradhatatlan patogenetikai „eszköz”, az Infl. törvényszerü komponense, az APR-ok egyik legerősebb tagja. Nem a lokális mennyiség a döntő; fontosabb a glikánok mennyisége, változása, a molekuláris kompozíció kvalitása, illetve a molekuláris makroés a mikroheterogenitás $[34,38,40]$.

Növekedik a plazmaorozomukoid-koncentráció a glükózszinttel (postload glükóz) együtt, ami a glükózterhelési próba értékelésekor figyelembe veendő [32]. PCPban terápia hatására jelentős javulás érhető el. A kezelt és jól válaszoló PCP-s betegek esetében még egy év után is jelentősek lehetnek az orozomukoidelváltozások. Bizonyos szérumglikán-változások sajátos hasonlóságot mutatnak PCP-ban és graviditásban. PCP-ban csökken a plazmában az IgG Fc típusú galaktoziláció, és növekedik a biantennáris szerkezetek aránya. Ez gyulladásos bélbetegségekben is elöfordul. Emelkedik a tri- és tetraantennáris szerkezetek aránya, a fukoziláció. Ez párhuzamos a sialyl-Lewis X felszaporodásával. Arthritisekben általában hasonló jelenségek észlelhetők. Inflammatoricus folyamatokban általános és egyedi inflammatoricus jelenségek is megjelennek. A tri- és tetraantennáris struktúrák, a fukoziláció és a sialyl-Lewis $\mathrm{X}$ változásai összefüggésben maradnak. A sialyl-Lewis X és a szelektinek (E és L) mennyisége között korreláció mutatkozik. A PCP-s és graviditásban észlelt változások részben fedésben vannak. Jelentősen növekszik a vizeletben az orozomukoidkiválasztás, amely egészségesekben általában igen alacsony. Fizikai megterhelés, heveny Infl., LED, hólyagtumorok és praeeclampsia esetében általában emelkedett mennyiségben fordul elő [33].

Enteritis regionalisban antilaminarin $(\operatorname{IgA})-$, antikitin (IgA)-, antikitobióz (IgA)-, antiglikán-pozitivitás észlelhető. A szövődmények korrelációt mutatnak a mennyiségi változásokkal. Antilaminarin-antitestek jelenléte se- bészeti beavatkozást igénylő esetekben progresszióra utal. LED-beli folyamatok a klinikai súlyosság és más szempontok alapján (újabb terápiás eljárások) elkülönítve is vizsgálatra kerültek [41]. Gátlóterápiák alkalmazására is sor került, például anti-Bly-, anti-Tly-, IL6-ellenes antitestek, TNF $\alpha$ - és komplementfaktor-ellenes terápiák stb. Ezek között anti-CD22, Bly-specifikus transzmembrán szialoglikoproteint tartalmazó célpont is szerepelt.

\section{Az orozomukoid és a sziálsav (Sia) elterjedtsége}

A humán szérumfehérjék csaknem kivétel nélkül GP-ek. Élettani esetben a humánszérum-GP-molekulák oligoszacharidláncai végső molekulája Sia. A vizeletben is ürülnek Sia-tartalmú oligos.-ból álló képződmények. A Sia az élővilágban példátlan elterjedtségnek örvend: a humán szervezet minden szervében megtalálható. Ezek a növény- és állatvilág fejlődését elősegítő alapstruktúrák a molekuláris formációtól a nagy molekulákig, sejtekig terjednek. Ezekből a növényi és állati egyedek élő struktúrákat építenek fel, amelyek némelyikének diagnosztikai, klinikai alkalmazásai is kutatás tárgyát képezik [42].

A humán szervezet Sia-tartalmáról, -funkciójáról már esett szó, így itt csak egyetlen konkrét előfordulásra térnénk ki. A microglia hordoz sejtfelszíni receptorokat az agyban, amelyek egyetlen Siglec-famíliába sorolhatók. A glycocalix Sia- „felhője” igen sajátos képződmény. Említést érdemelnek egyes mechanizmusok; sajátos szerepet kap az élettani és patológiás körülmények között az apoptózis, nekroptózis, nekrózis bekapcsolódása aktív folyamatokba, a neuronok épségének megtartásába, regenerációjába. Bizonyos, hogy a Siglec-szerep és -tevékenység, valamint a naturális és adaptációs immunitás múködése során elengedhetetlen a versengés. A Sia-specifikus felismerés és kapcsolatteremtés kizárólagos, figyelembe véve annak mikromodulációs, makromolekuláris módozatait is. A Sia-szerkezet stabilitása a mikroheterogenitás ellenére sem károsodik. A felismerés-kötődés-újrafelismerés a biológiai és gyógyszerhatású szerkezetek számát is valószínúleg növeli [43-45].

\section{Következtetések}

A Sia-alapmolekula régóta ismeretes, ám mégis viszonylag későn került a biológiai, biokémiai vizsgálatok sodrába. A molekula manapság mint az egyik legizgalmasabb jelenség áll a kutatási programok élén. Az elméleti ismeretek nagy mennyiségével rendelkezünk, amelyek az esetek nagy hányadában a klinikum területén a gyakorlatban eddig csak szórványosan hasznosultak [46, 47]. Fontos feladat lenne a fogalmak tartalmi megismerése, az eredmények tudatos beépítése a mindennapos tevékenységekbe, az orvoslásba. 
A Sia kilenc szénatomjához kötődő oldalláncok a beépülő atomok számát csak mérsékelten növelik, a kapcsolódó csoportok elhelyezkedése mellett a neuroaminosav meghatározó marad [48]. A derivátumok száma a beépülő gyököktől függően körülbelül 50 közelébe emelkedett. A Sia és a polisziálsav (polysialic acid) a természetben ubiquitaer alapmolekula. A Sia-molekulák száma, a derivátumok mennyisége tovább növekedhet új felismerések révén. A molekuláris struktúra és a származékok ott léteznek a növényvilágban, az egy- és soksejtes egyedek szöveteiben, miközben az alapmolekula is gazdagodik. A lehetséges orozomukoid glikoformok száma meghaladja a $10^{5}$-t. A derivátumok vizsgálata lehetővé teszi a diagnosztikus, prognosztikus értékü adatok megszerzését [49]. A glikánok mára felsorakoztak a nukleinsavak, proteinek, lipidek és más makromolekuláris építőelemek sorába, átalakítva a kutatások fősodrát.

Anyagi támogatás: A közlemény megírása anyagi támogatásban nem részesült.

A szerző a cikk végleges változatát elolvasta és jóváhagyta.

Érdekeltségek: A szerzőnek nincsenek érdekeltségei.

\section{Irodalom}

[1] Crispe IN. The liver as a lymphoid organ. Annu Rev Immunol. 2009; 27: 147-163.

[2] Wick G, Grundtman C, Mayerl C, et al. The immunology of fibrosis. Annu Rev Immunol. 2013; 31: 107-135.

[3] Crespo HJ, Lau, JT, Videira PA. Dendritic cells: a spot on sialic acid. Front Immunol. 2013; 4: 491.

[4] Crocker PR. Siglecs in innate immunity. Curr Opin Pharmacol. 2005; 5: 431-437.

[5] Crocker PR, Varki A. Siglecs, sialic acids and innate immunity. Trends Immunol. 2001, 22: 337-342.

[6] Bode JG, Albrecht U, Häussinger D, et al. Hepatic acute phase proteins - Regulation by IL-6- and IL-1-type cytokines involving STAT3 and its crosstalk with NF- $\mathrm{kB}$-dependent signaling. Eur J Cell Biol. 2012; 91: 496-505.

[7] Thomas S, Wolf SE, Chinkes DL, et al. Recovery from the hepatic acute phase response in the severely burned and the effects of long-term growth hormone treatment. BURNS 2004; 30: 675-679.

[8] Quinton LJ, Jones MR, Robson BE, et al. Mechanisms of the hepatic acute-phase response during bacterial pneumonia. Infect Immun. 2009; 77: 2417-2426.

[9] Fournier T, Medjoubi NN, Porquet D. Alpha-1-acid glycoprotein. Biochem Biophys Acta 2000; 1482: 157-171.

[10] Fernandes CL, Ligabue-Braun R, Verli H. Structural glycobiology of human $\alpha \mathrm{l}$-acid glycoprotein and its implications for pharmacokinetics and inflammation. Glycobiology 2015; 25: 11251133.

[11] Linnartz B, Neumann H. Microglial activatory (immunoreceptor tyrosine-based activation motif)- and inhibitory (immunoreceptor tyrosine-based inhibition motif)-signaling receptors for recognition of the neuronal glycocalyx. Glia 2013; 61: 37-46.

[12] Gomez IG, Tang J, Wilson C, et al. Metalloproteinase-mediated shedding of integrin $\beta 2$ promotes macrophage efflux from inflammatory sites. J Biol Chem. 2012; 287: 4581-4589.
[13] Moshage H. Cytokines and the hepatic acute phase response. J Pathol. 1997; 181: 257-266.

[14] Gunnarsson P, Levander L, Påhlsson P, et al. The acute-phase protein $\alpha \mathrm{l}$-acid glycoprotein (AGP) induces rises in cytosolic $\mathrm{Ca}^{2+}$ in neutrophil granulocytes via sialic acid binding immunoglobulin-like lectins (Siglecs). FASEB J. 2008; 21: 4059-4069.

[15] Grewal PK, Uchiyama S, Ditto D, et al. The Ashwell receptor mitigates the lethal coagulopathy of sepsis. Nat Med. 2008; 14: 648-655.

[16] Buzás EI, György B, Pásztói M, et al. Carbohydrate recognition systems in autoimmunity. Autoimmunity 2006; 39: 691-704.

[17] Jakab L. Acute phase reaction of the body. [A szervezeti ,acut phasis reactio".] Orv Hetil. 1993; 134: 563-568. [Hungarian]

[18] Gabay C, Kushner I. Acute-phase proteins and other systemic responses to inflammation. N Engl J Med. 1999; 340: 448-454.

[19] Arnold JN, Wormald MR, Sim RB, et al. The impact of glycosylation on the biological function and structure of human immunoglobulins. Annu Rev Immunol. 2007; 25: 21-50.

[20] Jakab L, Kalabay L. The acute phase reaction syndrome: the acute phase reactants. Acta Microbiol Immunol Hung. 1998; 45: 409-418.

[21] Ceciliani F, Pocacqua V. The acute phase protein $\alpha$ l-acid glycoprotein: a model for altered glycosylation during diseases. Curr Protein Pept Sci. 2007; 8: 91-108.

[22] Lehmann F, Tiralongo E, Tiralongo J. Sialic acid-specific lectins: occurrence, specificity and function. Cell Mol Life Sci. 2006; 63: $1331-1354$

[23] Kopecký V Jr, Ettrich R, Hofbauerová K, et al. Structure of human $\alpha \mathrm{l}$-acid glycoprotein and its high-affinity binding site. Biochem Biophys Res Commun. 2003; 300: 41-46.

[24] Varki A, Angata T. Siglecs - the major subfamily of I-type lectins. Glycobiology 2006; 16: 1R-27R.

[25] Gabay C, Kushner I. Acute-phase proteins and other systemic responses to inflammation. N Engl J Med. 1999; 340: 448-454.

[26] Huang RY, Hudgens JW. Effects of desialylation on human alacid glycoprotein-ligand interactions. Biochemistry 2013; 52: 7127-7136.

[27] Schönfeld DL, Ravelli RB, Mueller U, et al. The 1.8-A crystal structure of alphal-acid glycoprotein (orosomucoid) solved by UV RIP reveals the broad drug-binding activity of this human plasma lipocalin. J Mol Biol. 2008; 384: 393-405.

[28] Watanabe K, Ishima Y, Akaike T, et al. S-nitrosated $\alpha$-1-acid glycoprotein kills drug-resistant bacteria and aids survival in sepsis. FASEB J. 2013; 27: 391-398.

[29] Gieseke F, Böhringer J, Bussolari R, et al. Human multipotent mesenchymal stromal cells use galectin-1 to inhibit immune effector cells. Blood 2010; 116: 3770-3779.

[30] Rayes J, Roumenina LT, Dimitrov JD, et al. The interaction between factor $\mathrm{H}$ and VWF increases factor $\mathrm{H}$ cofactor activity and regulates VWF prothrombotic status. Blood 2014; 123: 121125.

[31] Jorgensen JM, Yang Z, Lönnerdal B, et al. Plasma ferritin and hepcidin are lower at 4 months postpartum among women with elevated C-reactive protein or $\alpha \mathrm{l}$-acid glycoprotein. J Nutr. 2017; 147: 1194-1199.

[32] Tsuboi A, Minato S, Yano M, et al. Association of serum orosomucoid with 30-min plasma glucose and glucose excursion during oral glucose tolerance tests in non-obese young Japanese women. BMJ Open Diabetes Res Care 2018; 6: e000508.

[33] Reiding KR, Vreeker GC, Bondt A, et al. Serum protein N-glycosylation changes with rheumatoid arthritis disease activity during and after pregnancy. Front Med. 2018; 4: 241.

[34] Singh-Manoux A, Shipley MJ, Bell JA, et al. Association between inflammatory biomarkers and all-cause, cardiovascular and cancer-related mortality. CMAJ 2017; 189: E384-E390.

[35] Muhammad IF, Borné Y, Östling G, et al. Acute phase proteins as prospective risk markers for arterial stiffness: The Malmö Diet and Cancer cohort. PLOS One 2017; 12: e0181718. 
[36] Kustán P, Horváth-Szalai Z, Mühl D. Nonconventional markers of sepsis. EJIFCC 2017; 28: 122-133.

[37] Zhao Q, Zhan T, Deng Z, et al. Glycan analysis of colorectal cancer samples reveals stage-dependent changes in CEA glycosylation patterns. Clin Proteomics 2018; 15: 9.

[38] Narita T, Hatakeyama S, Yoneyama T, et al. Clinical implications of serum $\mathrm{N}$-glycan profiling as a diagnostic and prognostic biomarker in germ-cell tumors. Cancer Med. 2017; 6: 739-748.

[39] Kostner KM, Kostner GM. Lipoprotein (a): a historical appraisal. J Lipid Res. 2017; 58: 1-14.

[40] Bao X, Borné Y, Johnson L, et al. Comparing the inflammatory profiles for incidence of diabetes mellitus and cardiovascular diseases: a prospective study exploring the 'common soil' hypothesis. Cardiovasc Diabetol. 2018; 17: 87.

[41] Varki, A. Biological roles of glycans. Glycobiology 2017; 27: 3-49.

[42] Jakab L. Glycosaminoglycans, proteoglycans, atherosclerosis. [Glikozaminoglikánok, proteoglikánok, atherosclerosis.] Orv Hetil. 2004; 145: 795-803. [Hungarian]

[43] Clark SJ, Ridge LA, Herbert AP, et al. Tissue-specific host recognition by complement factor $\mathrm{H}$ is mediated by differential activi- ties of its glycosaminoglycan-binding regions. J Immunol. 2013; 190: 2049-2057.

[44] Baldan-Martin M, de la Cuesta F, Alvarez-Llamas G, et al. Prediction of development and maintenance of high albuminuria during chronic renin-angiotensin suppression by plasma proteomics. Int J Cardiol. 2015; 196: 170-177.

[45] Stevens J, Blixt O, Tumpey TM, et al. Structure and receptor specificity of the hemagglutinin from an $\mathrm{H} 5 \mathrm{Nl}$ influenza virus. Science 2006; 312: 404-410.

[46] Yuki, N. Carbohydrate mimicry: a new paradigm of autoimmune diseases. Curr Opin Immunol. 2005; 17: 577-582.

[47] Varki A. Trousseau's syndrome: multiple definitions and multiple mechanisms. Blood 2007; 110: 1723-1729.

[48] Rademacher C, Bru T, McBride R, et al. A Siglec-like sialic-acidbinding motif revealed in an adenovirus capsid protein. Glycobiology 2012; 22: 1086-1091.

[49] Crocker PR, Paulson JC, Varki A. Siglecs and their roles in the immune system. Nat Rev Immunol. 2007; 7: 255-266.

(Jakab Lajos dr., Budapest, Kútvölgyi út 4., 1125 e-mail: nyulikinga@gmail.com)

\section{MEGHÍVÓ}

\section{A Magyar Hematológiai és Transzfúziológiai Társaság vezetősége tisztelettel meghívja valamennyi tagját a $\mathbf{2 7}$. Kongresszusára.}

HELYSZÍN: Kodály Központ

(7622 Pécs, Breuer Marcell sétány 4.)

IDŐPONT: 2019. május 23-25.

A kongresszus weboldala már elérhető a www.regio10.hu/mhtt2019 címen, itt folyamatosan tájékoztatást lehet kapni a kongresszusi tudnivalókról.

FONTOS HATÁRIDÖ:

Korai regisztráció: 2019. február 28.

\section{A KONFERENCIA KIEMELT TÉMÁI:}

- Aktualitások a heveny leukémiák diagnosztikájában és kezelésében.

- A myeloproliferatív neoplasmák kezelési ajánlásai (CML, PV, ET, MF).

- Szemléletváltozás a lymphoproliferatív betegségek terápiájában.

- Az allogén haemopoetikus őssejt-transzplantáció újdonságai.

- A vérzékenység aktualitásai (főként új kezelési lehetőségek a haemophiliában).

- Kihívások a transzfuziológiában a XXI. században.

A cikk a Creative Commons Attribution 4.0 International License (https://creativecommons.org/licenses/by/4.0/) feltételei szerint publikált Open Access közlemény, melynek szellemében a cikk bármilyen médiumban szabadon felhasználható, megosztható és újraközölhetö, feltéve, hogy az eredeti szerző és a közlés helye, illetve a CC License linkje és az esetlegesen végrehajtott módositások feltüntetésre kerülnek. (SID_1) 